\title{
Biosynthesis of secondary metabolites in sugarcane
}

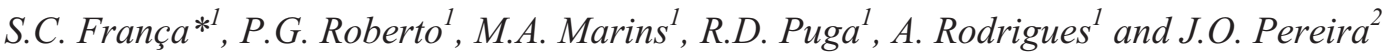

\begin{abstract}
A set of genes related to secondary metabolism was extracted from the sugarcane expressed sequence tag (SUCEST) database and was used to investigate both the gene expression pattern of key enzymes regulating the main biosynthetic secondary metabolism pathways and the major classes of metabolites involved in the response of sugarcane to environmental and developmental cues. The SUCEST database was constructed with tissues in different physiological conditions which had been collected under varied situation of environmental stress. This database allows researchers to identify and characterize the expressed genes of a wide range of putative enzymes able to catalyze steps in the phenylpropanoid, isoprenoid and other pathways of the special metabolic mechanisms involved in the response of sugarcane to environmental changes. Our results show that sugarcane cDNAs encoded putative ultra-violet induced sesquiterpene cyclases (SC); chalcone synthase (CHS), the first enzyme in the pathway branch for flavonoid biosynthesis; isoflavone synthase (IFS), involved in plant defense and root nodulation; isoflavone reductase (IFR), a key enzyme in phenylpropanoid phytoalexin biosynthesis; and caffeic acid-O-methyltransferase, a key enzyme in the biosynthesis of lignin cell wall precursors. High levels of CHS transcripts from plantlets infected with Herbaspirillum rubri or Gluconacetobacter diazotroficans suggests that agents of biotic stress can elicit flavonoid biosynthesis in sugarcane. From this data we have predicted the profile of isoprenoid and phenylpropanoid metabolism in sugarcane and pointed the branches of secondary metabolism activated during tissue-specific stages of development and the adaptive response of sugarcane to agents of biotic and abiotic stress, although our assignment of enzyme function should be confirmed by careful biochemical and genetic supporting evidence.
\end{abstract}

\section{INTRODUCTION}

Plants interact with their environment by producing a diverse array of secondary metabolites (Harborne, 1996). Many of these compounds are valued for their pharmacological activities and industrial or agricultural properties which increase the commercial value of crops (Paganga et al., 1999; Bingham et al., 1998).

There is an emerging body of evidence, based on biological activities in vitro and on the correlation between rates of accumulation and expression of resistance in vivo, which indicates that isoprenoid and phenylpropanoid compounds play a role in the induced and constitutive response of plants to biotic and abiotic agents (Dixon and Paiva,1995).

Although the isoprenoid pathway has, for the most part, been described in animals and fungi and many enzymes involved in various steps of isoprenoid biosynthesis have been measured in plants systems, a variety of essential and developmentally regulated isoprenoids are synthesized in plants but not in other eukaryotes and it remains to be validated whether or not this pathway is operative in plants.

Phenylpropanoids are involved in several functions and play a vital role in the interaction between plants and their environment. Many aromatic secondary metabolites are phenylpropanoids, e.g. flavonoids, phytoalexins, agents which protect against ultra-violet light and, most importantly, lignin (Mabry and Ulubelen,1980). Compounds that are constitutive in one plant species or tissue can be induced by various stresses in another species or in another tissue of the same plant (Beggs et al.,1987; Christie et al., 1994). Expression of the phenylpropanoid biosynthetic pathway is precisely regulated in response to developmental signals, nutrient status and environmental stimuli such as light, heat and pathogen attack. The accumulation of flavonoids and isoflavonoids under the attack of pathogens is used as a mechanism of detoxification by many species (Van Etten $e t$ al.,1989).

In most systems studied, the induction of isoprenoid and phenylpropanoid synthesis under conditions of stress is the result of increased transcription of genes encoding the corresponding biosynthetic enzymes (Alex et al., 2000; He et al., 1998; Fahrendorf and Dixon, 1993; Uhlmann and Ebel,1993).

Recombinant DNA technology offers new opportunities to directly modify plant secondary product synthesis through metabolic engineering, and the availability of cloned genes encoding terminal enzymes of isoprenoid or phenylpropanoid compounds may provide the means to assess product function by using reverse genetics (i.e. anti sense or sense suppression) in species that are amenable to

\footnotetext{
${ }^{1}$ Unidade de Biotecnologia Vegetal, Universidade de Ribeirão Preto - UNAERP, Av. Costábile Romano, 2201, 14096-380 Ribeirão Preto, SP, Brazil.

${ }^{2}$ Faculdade de Ciências Agrárias, Universidade do Amazonas - UA, Manaus, AM, Brazil. Send correspondence to S.C. França.E-mail: suzicf@odin.unaerp.br.
} 
genetic transformation. However, despite the increasing number of proteins isolated from plant species there is a lack of genes encoding key secondary metabolism enzymes.

The SUCEST database was constructed with tissues in different physiological conditions which had been developed under varied situation of environmental stress and represents a rich source from which to identify and characterize expressed genes of a wide range of putative enzymes able to catalyze steps in the phenylpropanoid, isoprenoid and other pathways of the special metabolic mechanisms related to the response of sugarcane to environmental changes. In addition, because the protein structure of most enzymes involved in secondary metabolism is conserved, cloned genes from sugarcane may be useful as probes for the isolation of related genes from other monocotyledon (or even dicotyledon) species.

The work described in this paper was carried out to produce a collection of genes related to secondary metabolism and also to investigate the gene expression pattern of key enzymes which regulate the main biosynthetic routes of secondary metabolism, uncovering the major classes of metabolites that play a role in the response of sugarcane to environmental and developmental cues.

\section{MATERIALS AND METHODS}

\section{Source library}

The source tissues, sugarcane variety and the codes used in this paper are shown in Table I.

\section{Isoprenoid pathway enzymes}

In the main trunk of the isoprenoid pathway the enzymes squalene synthetase (SQS - EC 2.5.1.21) (Porter and Spurgeon, 1981) and sesquiterpene cyclase (SC - EC 2.1.5.) (Cane,1981) are the first branch point enzymes for sterol and sesquiterpenoid biosynthesis competing for the last common intermediate between the two branches, farnesyl diphosphate (FPP). FPP is also a precursor for the biosynthesis of other polyprenyl-lipids and isoprenoids including carotenoids, gibberellic acid, ubiquinones and dolichols (Porter and Spurgeon, 1981). Cycloartenol synthase (CAS - EC 5.4.99.8), another enzyme involved in isoprenoid metabolism, converts oxidosqualene to cycloartenol, the first carbocyclic intermediate in the route to sterols in plants.

A cDNA clone (GgCAS1) encoding CAS was isolated from Glycyrrhiza glabra (licorice) by cross-hybridization with a probe of Pisum sativum CAS. The deduced amino acid sequence of GgCAS1 exhibited $89 \%, 83 \%$ and $81 \%$ identity to $P$. sativum, Panax ginseng and Arabidopsis thaliana CASs, respectively (Husselstein-Muller et al., 2001). Protein sequences from these plants were used as
Table I - Library codes of the sugarcane source tissues and varieties used in this study.

\begin{tabular}{|c|c|c|}
\hline Library code & Sugarcane variety & Source tissue \\
\hline $\mathrm{AD}$ & SP70-1143 & $\begin{array}{l}\text { Plantlets without developed } \\
\text { leaves but with roots infected } \\
\text { with Gluconacetobacter } \\
\text { diazotroficans }\end{array}$ \\
\hline $\mathrm{AM}$ & SP80-3280 & $\begin{array}{l}\text { Apical meristem and young } \\
\text { leaves and stem of mature } \\
\text { plants } \mathrm{s}^{\mathrm{b}}\end{array}$ \\
\hline $\mathrm{CL}$ & SP80-3280 & Calli $^{\mathrm{a}}$ \\
\hline FL & $\begin{array}{l}\text { SP80-87432 } \\
\text { PB5211 X P57150-4 }\end{array}$ & Flowers $^{\mathrm{c}}$ \\
\hline HR & SP70-1143 & $\begin{array}{l}\text { Plantlets without developed } \\
\text { leaves but with roots infected } \\
\text { with Herbaspirillum rubri } \\
\text { (subspecies albicans) }^{\mathrm{a}}\end{array}$ \\
\hline LB & SP80-3280 & Lateral buds from plants ${ }^{\mathrm{c}}$ \\
\hline LR & SP80-3280 & Rolled leaves from plants ${ }^{c}$ \\
\hline LV & $\begin{array}{l}\text { SP83-5077, SP80-185, } \\
\text { SP87-396, SP80-3280, } \\
\text { SP803280 x SP81-5441 }\end{array}$ & $\begin{array}{l}\text { Etiolated leaves from } \\
\text { plantlets }^{\mathrm{a}}\end{array}$ \\
\hline RT & SP80-3280 & Roots from plants ${ }^{\mathrm{c}}$ \\
\hline $\mathrm{RZ}$ & SP80-3280 & $\begin{array}{l}\text { Leaf-root transition zone of } \\
\text { immature plants }{ }^{\mathrm{c}}\end{array}$ \\
\hline SB & SP80-3280 & Stem bark from plants ${ }^{\mathrm{c}}$ \\
\hline SD & & $\begin{array}{l}\text { Seeds in different stages of de- } \\
\text { velopment }^{\mathrm{d}}\end{array}$ \\
\hline ST & SP80-3280 & $\begin{array}{l}\text { Stem-tissue from the first and } \\
\text { fourth internodes of plants }{ }^{c}\end{array}$ \\
\hline
\end{tabular}

${ }^{\mathrm{a}}$ Grown in vitro.

${ }^{\mathrm{b}}$ Grown in a green house at Centro de Biologia Molecular e Engenharia Genética (CBMEG) Universidade Estadual de Campinas. C.P. 6109, Campinas, SP, Brazil.

${ }^{\mathrm{c}}$ Grown at the experimental station of Cooperativa de Produtores de Açucar e Alcool (COPERSUCAR), Piracicaba, SP, Brazil.

${ }^{\mathrm{d}}$ Collected at the experimental station of the Universidade Federal de Alagoas (UFAL) Muricí, Al, Brazil.

For more details on library source see: http://sucest.lad.ic.unicamp.br.

virtual probe to search for CAS genes in the SUCEST database.

\section{Phenylpropanoid pathway enzymes}

The phenylpropanoid biosynthesis pathway produces compounds with the basic C6-C3 carbon skeleton of phenylalanine, and a wide range of proteins involved in the main steps of this pathway have been identified in higher plants. e.g. chalcone synthase (CHS - EC 2.3.1.74), chalcone isomerase (CHI - EC 5.5.1.6); isoflavone synthase (IFS - EC1.14.14), isoflavone reductase (IFR - EC 1.3.1.45), isoflavone isomerase, 0-methyltransferase (OMT - EC 2.1.1.104), coumarate hydroxylase (C4H - EC 1.14.13.11), coumarate ligase (4CL - EC 6.2.1.12) and stilbene (or resveratrol) synthase (SS - EC 2.3.1.95). Protein sequences of these enzymes deposited in the GenBank 
database were used as virtual probes to search for genes of the phenylpropanoid pathway in sugarcane.

A search of the SUCEST database, using the basic local alignment search tool (BLAST) (Altschul et al., 1990), with proteins previously isolated from other plant species led us to identify DNA sequences with high homology to catalytic proteins of the isoprenoid and phenylpropanoid metabolism pathway. These clones were sequenced and when the putative products were compared to the published amino acid sequences for the corresponding enzymes the best percentages of similarity ranged from $65 \%$ to $93 \%$. Multiple alignment, using the Clustal $\mathrm{X}$ program of Jeanmougin et al. (1998), of full length sequence of sugarcane with similar proteins showed the transcripts which are closely related to the protein structure of each key enzyme of the main branches of the isoprenoid and phenylpropanoid pathways in plants.

\section{RESULTS}

Isoprenoid metabolism

\section{Sesquiterpene cyclase}

The abundance of sugarcane expressed sequence tags (ESTs) and putative isoprenoid and phenylpropanoid related enzymes is shown in Table II, abundance being shown as the number of enzyme related transcripts divided by the number of ESTs in the SUCEST library.
Comparative analysis between the deduced amino acid sequences from the SUCEST database and genes coding for sesquiterpene cyclase (SC) showed that the SCSBFL1107C10 sequence is $44 \%$ related to the a (+)-delta-cadinene synthase gene gi:8389329 which is involved in the biosynthesis of sesquiterpene aldehydes in the plant Gossypium arboreum L. (Tan et al., 2000) and that the SCCCFL4O89E11 sequence has a similarity of $45 \%$ in relation to an ultra-violet induced sesquiterpene cyclase gene gi: 6644409 from Capsicum annum. In addition, sequence SCEQAD1018E06 has a 44\% resemblance to the gene gi: 5360687 which codes for a vetispiradiene synthase expressed in potato tubers infected with Phytophthora infestans (Yoshioka et al., 1999). Based on the abundance and type of transcripts identified we suggest that sugarcane flower and leaf tissues express sesquiterpene cyclases from the TPSa subgroup of angiosperms.

\section{Squalene synthases}

A search of the SUCEST database with genes encoding squalene synthases (SQS) from Oryza sativa (gi:2463565) Zea mays (gi: 7434086) and $P$. ginseng (gi:2780361) showed putative squalene synthase cDNAs of which the best match was the sequence SCCCRT2002B10 which shared 93\% identity with the gi:7434086 gene from Z. mays. Multiple sequence alignment between SQS-related sequences from sugarcane, monocotyledons and dicotyledons reinforce the assumption made by Hata et al.

Table II - Abundance of sugarcane expressed sequence tags (ESTs) and putative isoprenoid and phenylpropanoid related enzymes. Abundance is shown as the number of enzyme related transcripts divided by the number ESTs in the library.

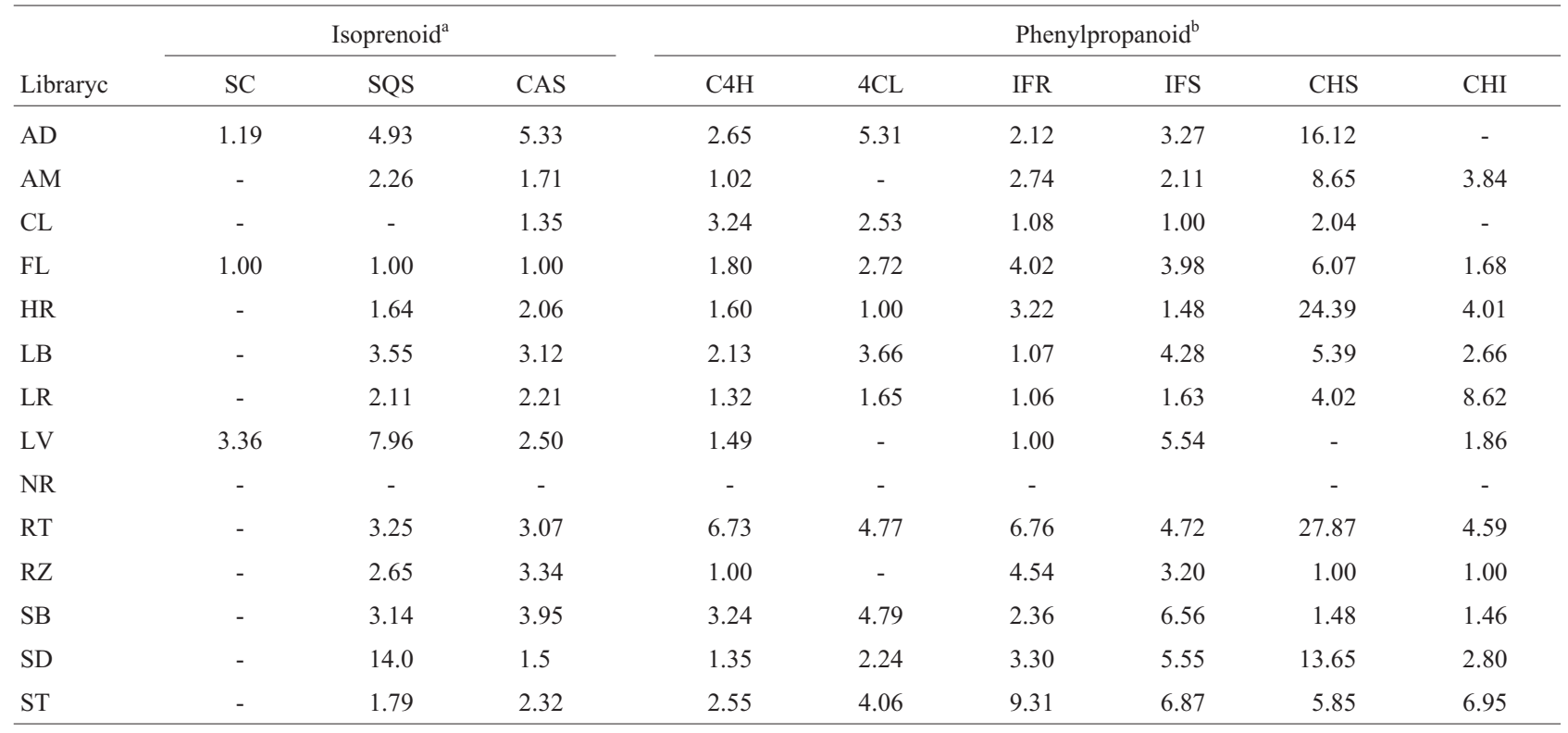

${ }^{a}$ Abundance of putative isoprenoid related sugarcane ESTs ( SC = sesquiterpene cyclase; SQS = squalene synthase; CAS = cycloartenol synthase).

${ }^{\mathrm{b}}$ Abundance of putative phenylpropanoid related sugarcane ESTs $(\mathrm{C} 4 \mathrm{H}=$ coumarate hydroxylase, $4 \mathrm{CL}=$ coumarate ligase; IFR $=$ isoflavone reductase, IFS = isoflavone synthase, $\mathrm{CHS}=$ halcone synthase $\mathrm{CHI}=$ chalcone isomerase).

${ }^{\mathrm{C}}$ For library key see Table I. 
(1997) that SQS from monocotyledons and dicotyledons form distinct evolutionary subgroups.

\section{Cycloartenol cyclases}

Four sugarcane cDNAs were isolated and sequenced on both strands and the deduced amino acid sequences were compared to cycloartenol cyclases (CAS) from other plant species, the results revealing three groups of related putative sugarcane cycloartenol cyclases with similarity to genes from O. sativa (gi: 6090879) A. thaliana (gi: 6598481), P. sativum (gi: 7447118), G. glabra (gi: 4589852) and $P$. ginseng (gi: 3688598) (Figure 1).

Since they are key enzymes at branch points of the main trunk of the isoprenoid pathway the putatively identified squalene synthase and sesquiterpene cyclase genes may control the level of expression of different isoprenoid classes in sugarcane tissues. The expression pattern of SQS and CAS in the AD tissue-library indicates that the branch for sterol biosynthesis is active in plantlets infected with Gluconacetobacter diazotroficans, suggesting that sugarcane produces phytosterols in response to this bacteria. (Table III). On the other hand, the expression of the phenylpropanoid pathway enzymes IFS, CHS and $\mathrm{CHI}$ in plantlets infected with Herbaspirillum rubri (HR tissue-library) showed that different biosynthetic branches were activated (Table III).

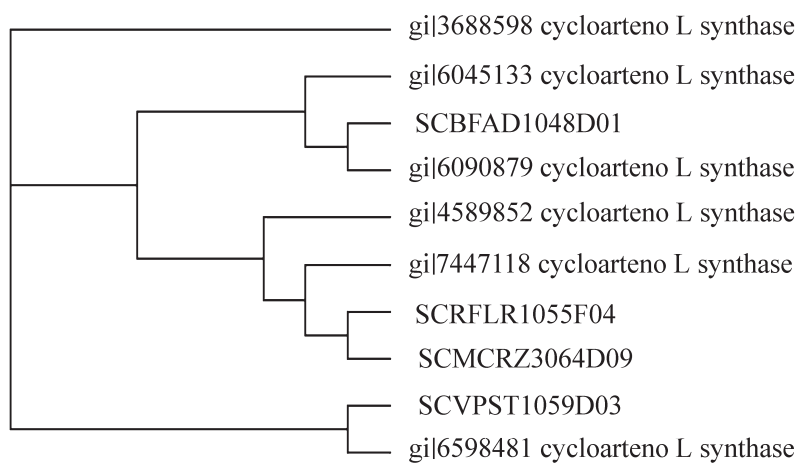

Figure 1 - Cladogram of sugarcane cDNAs coding for putative cycloartenol synthase (CAS) and CAS genes from other monocotyledonous and dicotyledonous species.

gi:3688598 Panax ginseng; gi:6045133 Orysa sativa; gi:6090879 Orysa sativa; gi:4589852 Glycyrrhiza glabra; gi:7447118 Garden pea.

* Multiple alignment analysis was performed with Clustal X program (www.igbmc.u-strasbg.fr). The length of the horizontal lines indicates an inverse degree of relatedness.
In cell cultures of Nicotiana tabacum treated with a fungal elicitor, biotic elicitation can also cause coordinated inhibition of squalene synthase and induction of sesquiterpene cyclase resulting in a rapid decrease in phytosterol biosynthesis coincident with the induction and accumulation of novel terpenoids involved in the plant defense response (Threlfall and Whitehead, 1988; Voegeli and Chappell, 1988).

In the cDNA libraries constructed with various tissues of sugarcane variety SP 80-3280, comparison of the gene expression pattern related to the isoprenoid pathway indicated that stem bark (SB-library) and lateral buds (LB-library) are probable sites of biosynthesis of terpenoid and steroid compounds. Stem bark tissue also expressed genes related to the biosynthesis of lignin precursors and isoflavonoid compounds. In addition, high level expression of phenylpropanoid genes was detected in first and fourth internode tissues (ST-library) which suggests that metabolic routes for the biosynthesis of more complex phenylpropanoids are active in this tissue. Rolled leaves seem to be the site for the synthesis of flavonone-like metabolites. Moreover, in root tissue, high levels of $\mathrm{CHS}$ and $\mathrm{C} 4 \mathrm{H}$ (which regulates the biosynthesis of the substrate for chalcone synthase) indicate that products such as tetrahydrochalcone may accumulate in this tissue (Table IV).

\section{Phenylpropanoid metabolism}

\section{Chalcone synthase and chalcone isomerase}

Sequences matching chalcone synthase (CHS) and chalcone isomerase (CHI) (enzymes committed to the central branch of the flavonoid biosynthesis pathway) were detected in the SUCEST database. The clones found were full-length sequenced and the transcripts compared to corresponding genes from other plant species. It was found that the sugarcane CHS protein sequences were similar to the sorghum genes encoding proteins CHS 1 (gi: 5005907), CHS 2 (gi: 5005909) and CHS 3 (gi: 5005911) as well as to the Maize gene gi: 116380 which also shared high identity with the sugarcane sequence SCEZRT2018G01 (Figure 2).

\section{Isoflavone synthase}

Isoflavone synthase (IFS) catalyzes the first committed step of isoflavone biosynthesis, a branch of the phenylpropanoid pathway. Isoflavones have received much

Table III - Gene expression pattern of tissues from sugarcane variety SP $70-1143$. Values represent the ratio of enzyme related transcript abundance $\left(\mathrm{x} 10^{5}\right)$ multiplied by the total reads of the library in the SUCEST database.

\begin{tabular}{|c|c|c|c|c|c|c|c|c|c|c|}
\hline \multirow[b]{2}{*}{ Library } & \multicolumn{3}{|c|}{ Isoprenoid } & \multicolumn{7}{|c|}{ Phenylpropanoid } \\
\hline & $\mathrm{SC}$ & SQS & CAS & $\mathrm{C} 4 \mathrm{H}$ & $4 \mathrm{CL}$ & IFR & IFS & CHS & $\mathrm{CHI}$ & Total reads \\
\hline $\mathrm{AD}$ & 6.56 & 27.18 & 29.38 & 14.61 & 29.27 & 11.68 & 18.02 & 88.87 & - & 18.137 \\
\hline HR & - & 13.66 & 17.16 & 12.00 & 13.33 & 8.33 & 26.83 & 203.25 & 22.10 & 12.000 \\
\hline
\end{tabular}

${ }^{\mathrm{C}}$ For library key see Table I. 
Table IV - Gene expression pattern of tissues from sugarcane variety SP $80-3280$. Values represent the ratio of enzyme related transcript abundance $\left(\mathrm{x} 10^{5}\right)$ multiplied by the total reads of the library in the SUCEST database.

\begin{tabular}{|c|c|c|c|c|c|c|c|c|c|c|}
\hline \multirow[b]{2}{*}{ Library $^{\mathrm{c}}$} & \multicolumn{3}{|c|}{ Isoprenoid $^{\mathrm{a}}$} & \multicolumn{7}{|c|}{ Phenylpropanoid $^{\mathrm{b}}$} \\
\hline & $\mathrm{SC}$ & SQS & CAS & $\mathrm{C} 4 \mathrm{H}$ & $4 \mathrm{CL}$ & IFR & IFS & CHS & CHI & Total reads \\
\hline AM & - & 8.03 & 6.07 & 3.62 & - & 9.74 & 7.50 & 30.75 & 13.65 & 28.128 \\
\hline LB & - & 19.67 & 17.28 & 11.80 & 20.28 & 5.92 & 23.71 & 29.86 & 14.73 & 18.047 \\
\hline LR & - & 11.63 & 12.18 & 7.27 & 9.09 & 5.84 & 8.98 & 22.15 & 47.51 & 18.141 \\
\hline RT & - & 10.32 & 9.75 & 21.37 & 15.14 & 21.46 & 14.99 & 88.51 & 14.57 & 31.487 \\
\hline $\mathrm{RZ}$ & - & 10.99 & 13.86 & 4.15 & - & 18.84 & 13.28 & 4.15 & 4.15 & 24.096 \\
\hline SB & - & 19.24 & 24.20 & 19.85 & 29.35 & 14.46 & 40.20 & 9.06 & 8.94 & 16.318 \\
\hline ST & - & 8.62 & 11.17 & 12.28 & 19.55 & 44.84 & 33.08 & 28.17 & 33.47 & 20.762 \\
\hline
\end{tabular}

${ }^{a} \mathrm{SC}=$ sesquiterpene cyclase, $\mathrm{SQS}=$ squalene synthase, $\mathrm{CAS}=$ cycloartenol synthase.

${ }^{\mathrm{b}} \mathrm{C} 4 \mathrm{H}=$ coumarate hydroxylase, $4 \mathrm{CL}=$ coumarate ligase; IFR $=$ isoflavone reductase, IFS $=$ isoflavone synthase, CHS = chalcone synthase; $\mathrm{CHI}=$ chalcone isomerase)

${ }^{\mathrm{C}}$ For library key see Table I.

attention because of their benefits to human health. These compounds are thought to be produced almost exclusively in legumes and play natural roles in plant defense and root nodulation. Genes involved in isoflavone biosynthesis were isolated from sugarcane, sequenced and the putative products showed similarities in their sequences to IFS genes from sorghum (gi: 5915857, 97\% similarity) and $A$. thaliana (gi: 4895205 (70\%) and gi: $5915859(69 \%)$ ).

\section{Isoflavone reductase}

Isoflavone reductase (IFR) is an enzyme specific to isoflavonoid biosynthesis, a pathway so far only found in legumes. It catalyses a NADPH-dependent reduction involved in the biosynthesis of important and related phenylpropanoid-derived plant defense compounds. IFR has been cloned from alfalfa and pea, and it has been demonstrated that when IFR is expressed in Escherichia coli it has the same substrate and product specificity as the purified native plant enzyme (Paiva et al.,1991,1994). In our work we isolated three related IFR-like sugarcane cDNAs, sequence SCVPLB1020E05 similar to the Z. mays gene gi: 1708421 which encodes isoflavone reductase (a NADPH-binding

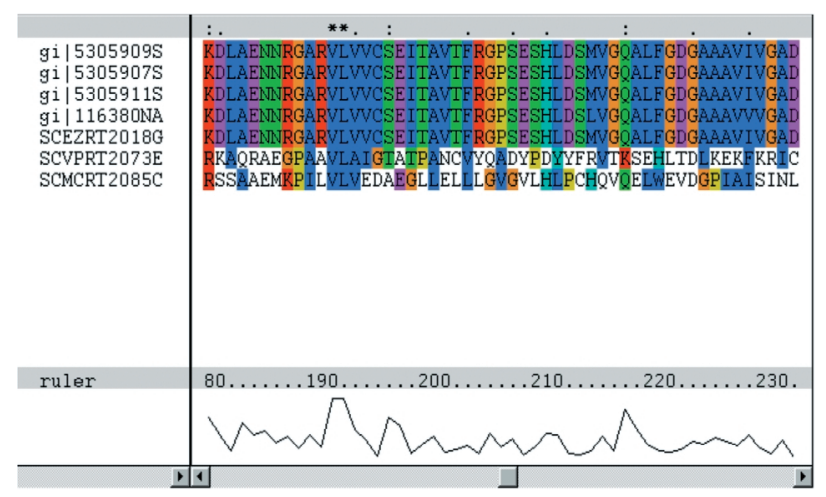

Figure 2 - Multiple alignment of full length sugarcane sequences and chalcone synthase (CHS) genes from sorghum and maize.

Sorghum (gi:5005907; gi:5005909; gi:5005911) and maize (gi:116380).

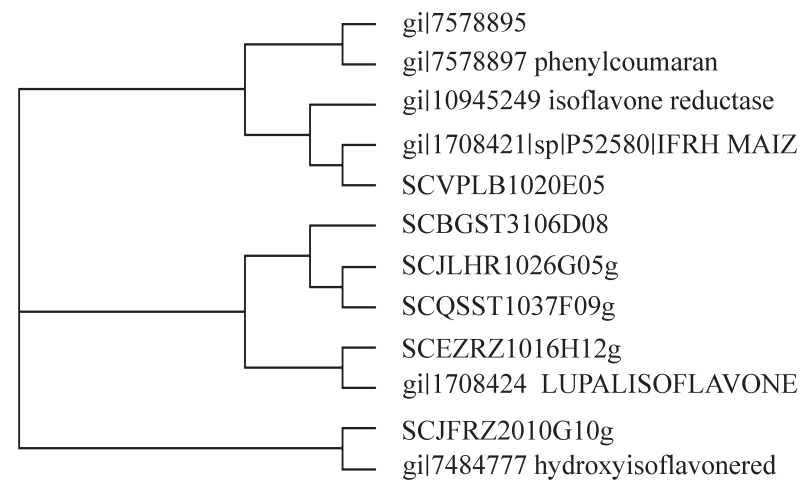

Figure 3 - Cladogram of cDNAs coding for putative isoflavone reducthases and corresponding IFR genes from other plants.

* Multiple alignment analysis was performed with Clustal X program (www.igbmc.u-strasbg.fr).

The length of the horizontal lines indicates an inverse degree of relatedness.

gi:7484777 Arabidopsis; gi:1708424 Lupinus albus; gi:1708421 Zea mays.

enzyme activated in response to sulfur starvation), the SCEZRZ1016H12 sequence with homology to the Lupinus albus gene gi: 1708424 which codes for an isoflavone reductase-like protein and the SCJFRZ2010G10 sequence which shares identity with the $A$. thaliana gene gi: 7484777 (Figure 3).

\section{O-methyltransferases}

Our search of the SUCEST database revealed sequences with similarities to O-methyltransferases (OMT) from various sources and classes. The highest matches (97-100\% identity) were found between the gi: 3341509 caffeoyl 3-O-methyltransferase (involved in lignification) gene from Saccharum officinarum and the sugarcane expressed sequence transcripts SCQSRT2031E06, SCCCRT 1003A12, SCRFLR1012F12 and SCVPRT2073D10. Expressed sequences from apical meristem (AM-library) were 
94\% identical to the caffeoyl 3-O-methyltransferase gene gi: 5101868 from $Z$. mays. The putative protein SCQGRT1039F03 was 59\% similar to the gi: 1353193 gene encoding maize OMT (ZRP4) and may be involved in the O-methylation of suberin phenylpropanoid precursors, while root-tissue (RT-library) OMT-type expressed sequences showed $51 \%$ homology with a herbicide safener-binding protein, antidote used to protect crops from herbicide injury, from Z. mays (gi:7447882). The relative abundance of the identified transcripts indicated that putative OMT proteins from sugarcane accumulate preferentially in the roots, because we detected low frequencies of these transcripts in leaf, stem and other aerial tissues.

\section{DISCUSSION}

Several phenylpropanoids (e.g. coumaric acid and simple coumarins) are produced from cinnamate via a series of hydroxylation, methylation and dehydration reactions. A large number of phenylpropanoids are derived from the $\mathrm{C} 15$ flavonoid skeleton which is synthesized via the CHS-catalyzed condensation of p-coumaroyl-coenzyme A and three molecules of malonyl-CoA (Harborne, 1988). In most plant families, the initial product of CHS is a tetrahydroxychalcone which is further converted to other flavonoid classes (Holton and Cornish, 1995). When both CHS and CHR are expressed, as in legumes, a trihydroxychalcone is formed and further transformed to its isomer by the action of CHI (Welle and Grisebach, 1989).

The abundance of clones for putative enzymes of both the central phenylpropanoid pathway and specific branch pathways of isoflavonoid or furanocoumarin synthesis in each source library of the SUCEST database suggest that CHS is active in root-tissue (RT-library) where it catalyzes the biosynthesis of chalcones which may be converted to flavonoid derivatives by $\mathrm{CHI}$ in rolled-leaves (LR-library) and stem-tissue from the first and fourth internodes (ST-library) where, in the presence of IFS and IFR, the flavonoid skeleton can probably be re-arranged leading to the accumulation of various simple isoflavonoids or more complex flavonoid derivatives. Ultra-violet radiation induces flavonoids (particularly kaempferol derivatives) and sinapate esters in A. thaliana and isoflavonoids and psoralens (furanocoumarin) in other species. These UV-absorbing compounds are thought to protect against the damage and subsequent cell death caused by UV-B by protecting DNA from dimerization and breakage (Beggs et al., 1985; Lois, 1994).

In healthy tissues the highest level of CHS transcripts were detected in roots, consistent with the biosynthesis of flavonoid derivatives in these tissues (Table II). The high frequency of CHS transcripts from plantlets infected with H. rubri or G. diazotroficans suggests that biotic stress agents cause elicitation of flavonoid biosynthesis in sugarcane species (Table III).
In our search we found sugarcane cDNA sequences with similarity to a Forsythia intermedia gene encoding $(+)$-pinoresinol/(+)-lariciresinol reductase, which, according to Dinkova-Kostova et al. (1996), regulates a pivotal branch point in lignan biosynthesis. The amino acid sequence of this enzyme reveals a strong homology to isoflavone reductase, a key branch point enzyme in isoflavonoid metabolism which is mainly found in the Leguminosae (angiosperms). Lignans are a widely distributed class of natural products, whose functions and distribution suggest that they are one of the earliest forms of defense mechanism to have evolved in vascular plants, whereas the isoflavonoids produced by isoflavone-reductase are mainly restricted to the Leguminosae. In fact, further evidence as to which specific class of secondary compounds sugarcane defense products belong would contribute to the understanding of the evolution of plant defense mechanisms.

Metabolic engineering for the production of isoflavones in non-legume dicotyledon and monocotyledon tissues may provide additional human health benefits due to the more wide consumption of grains containing these phyto-oestrogens (Bingham et al., 1998). It has been proved that in legumes, isoflavones act in both the symbiotic relationship with rhizobial bacteria and the plant defense response (Phillips and Kapulnik, 1995; Savoure et al.,1994).

Although, the accumulation of indole alkaloid metabolites in sugarcane has not been so far reported, the unexpected finding of putative strictosidine synthase (Str) genes in the flower, root and leaf-roll tissue cDNA libraries suggests that the indole pathway is active in sugarcane. The amino acid deduced sequence for the SCUTFL1064 sequence had an $83 \%$ similarity to the gi: 5777623 gene which codes for Str in Oryza sativa.

Although the assignment of enzyme function must be confirmed by further biochemical and/or genetic evidence, this work has allowed us to anticipate the isoprenoid and phenylpropanoid metabolism profile of sugarcane. It has also indicated the branch pathways of secondary metabolism activated during different tissue-specific developmental stages and under adaptive response to biotic and abiotic stress agents.

The information on expression patterns within the various sugarcane tissues provided in this paper can be used to handle the production of a specific metabolite within the plant using biochemical and genetic manipulation of secondary metabolism, which up to now has mainly been studied in medicinal plants at the final product level. The increasing amount of data on genome sequences from different plant species is changing our view of how widespread these pathways are in the plant kingdom, bringing us to the question 'is every plant a potential medicinal plant?'. Genomics is opening a 'molecular avenue' to the study of plant secondary metabolism which will enable us to study the genes coding for the key metabolic enzymes, their mo- 
lecular regulation and ecological and physiological roles as well the evolutionary significance of the pathway involved. This connection between the phytochemistry of natural products and genomics will allow the exploration of a wide range of plants for biotechnological purposes.

\section{RESUMO}

Este trabalho foi realizado com os objetivos de gerar uma coleção de genes relacionados ao metabolismo secundário da cana de açúcar e investigar o padrão de expressão gênica de enzimas chaves reguladoras das principais vias biossintéticas ativas nos diferentes tipos de tecidos e situações de estresse físico-químico e biológico a que estão submetidas plantas cultivadas em casas de vegetação, campo ou in vitro. A estratégia de mineração dos dados da database de sequências expressas de cana de açúcar, SUCEST, usando ferramentas de bioinformática, focalizou classes de compostos como isoprenóides e fenilpropanóides que comprovadamente desempenham um papel na resposta de plantas a variações ambientais. Foram identificados e caracterizados genes que codificam enzimas chaves para a síntese de terpenóides, como a sesquiterpeno ciclase (SC); (CHS) para síntese de flavonóides; isoflavona sintase (IFS) envolvida na biossíntese de isoflavonóides que desempenharm importante papel na defesa de plantas e nodulação de raízes; isoflavona redutases (IFR) enzimas chaves para a síntese de fenilpropanóide fitoalexinas, bem como enzimas relacionadas à síntese de precursores de lignina, como a enzima ácido caféico- O- metiltransferase.

$\mathrm{O}$ efeito do estresse causado por bactérias como $\mathrm{Her}$ baspirillum rubri e Gluconacetobacter diazotroficans também foi avaliado tendo sido constatada a indução da expressão de chalcona sintase (CHS) em plântulas infectadas com esses agentes, sugerindo a ativação da via de flavonóides em resposta a este estresse biológico. Esses resultados apontam para o fato de que as vias do metabolismo de isopropanóides e de fenilpropanóides em cana de açúcar são ativadas de acordo com o estágio de desenvolvimento, especificidade de tecidos e em resposta a situações de estresse. Essas observações deverão ser confirmadas por meio de experimentação genética e bioquímica.

\section{ACKNOWLEDGMENTS}

We thank the coordinator of SUCEST, Dr. Paulo Arruda, for his leadership during this work and Prof. Rosane de Castro França for reviewing the English version of the manuscript. Financial support was provided by the Brazilian agencies FAPESP and UNAERP.

\section{REFERENCES}

Alex, D., Bach, T.J. and Chye, M.L. (2000). Expression of Brassica juncea 3-hydroxy-3-methylglutaryl CoA synthase is developmentally regulated and stress-responsive. Plant $J$. 22: 415-26.
Altschul, S.F., Gish, W., Miller, W., Myers, E.W. and Lipman, D.J. (1999). Basic local alignment search tool. Bioinformatics 15: 862- 863.

Beggs, C.J., Stoltzer-Jehle, A. and Wellman, E. (1985). Isoflavonoid formation as an indicator of UV stress in bean (Phaseolus vulgaris L.) leaves: The significance of photo-repair in assessing potential damage by increased solar UV-B radiation. Plant Physiol. 79: 630-634.

Beggs, C.J., Kuhn, K., Böcker, R. and Wellman, E. (1987). Phytochrome induced flavonoid biosynthesis in mustard (Sinapsis alba L.) cotyledons: Enzymic control and differential regulation of anthocyanin and quercetin formation. Planta 172: 121-126.

Bingham, S.A., Atkinson, C., Liggins, J., Bluck, L. and Coward, A. (1998). Phyto-oestrogens: Were are we now? Br. J. Nutr. 79: 393-406.

Cane, D.E. (1981). Biosynthesis of sesquiterpene. In: Biosynthesis of Isoprenoid Compounds, (Porter, J.W. and Spurgeon, S.L. eds.) v. 1 and 2. John Wiley \& Sons, New York, NY. 1981.

Christie, P.J., Alfenito, M.R. and Walbot, V. (1994). Impact of low temperature stress on general phenylpropanoid and anthocyanin pathways: Enhancement of transcript abundance and anthocyanin pigmentation in maize seedlings. Planta 194: 541-549.

Dinkova-Kostova, A.T., Gang, D.R., Davin, L.B., Bedgar, D.L., Chu, A. and Lewis, N.G. (1996). (+)-Pinoresinol/(+)-lariciresinol reductase from Forsythia intermedia. Protein purification, cDNA cloning, heterologous expression and comparison to isoflavone reductase. J. Biol Chem. 27: 29473-82

Dixon, R.A. and Paiva, N.L. (1995). Stress induced phenylpropanoid metabolism. The Plant Cell 7: 1085-1097.

Fahrendorf, T. and Dixon, R.A. (1993). Stress responses in alfalfa (Medicago sativa L.). XVIII: Molecular cloning and expression of the elicitor-inducible cinnamic acid 4-hydroxylase cytochrome P450. Arch Biochem Biophys 305: 509-15.

Harborne, J.B. (1996). Recent advances in chemical ecology. Natural Products Report 12: 83-98.

Harborne, J.B. ed. (1988). The flavonoids: Advances in research since 1980. New York: Chapman \& Hall.

Hata, S., Sanmiya, K., Kouchi, H., Matsuoka, M., Yamamoto, N. and Izui, K. (1997). cDNA cloning of squalene synthase genes from mono- and dicotyledonous plants, and expression of the gene in rice. Plant Cell Physiol 38: 1409- 1413.

He, X.Z., Reddy, J.T. and Dixon, R.A. (1998). Stress responses in alfalfa (Medicago sativa L). XXII. cDNA cloning and characterization of an elicitor-inducible isoflavone 7-O-methyltransferase. Plant. Mol. Biol. 36: 43-54.

Holton, T.A. and Cornish, E.C. (1995). Genetics and biochemistry of anthocyanin biosynthesis. Plant Cell 7: 907-919.

Husselstein-Muller, T., Schaller, H. and Benveniste, P. (2001). Molecular cloning and expression in yeast of 2,3-oxidosqualene-triterpenoid cyclases from Arabidopsis thaliana. Plant Mol. Biol. 45: 75-92.

Jeanmougin, F., Thompson, J.D., Gouy, M., Higgins, D.G. and Gibson, T.J. (1998). Multiple sequence alignment with Clustal X. Trends Biochem. Sci. 23: 403- 405.

Lois, R. (1994). Accumulation of UV-absorbing flavonoids induced by UV-B radiation in Arabidopsis thaliana L. I. Me- 
chanisms of UV-resistance in Arabidopsis. Planta 194: 498-503.

Mabry T.J., and Ulubelen A. (1980). Chemistry and utilization of phenylpropanoids including flavonoids, coumarins, and lignans. J. Agric. Food Chem. 28: 188-95.

Paganga, G., Miller, N. and Rice-Evans, C.A. (1999). The polyphenolic content of fruit and vegetables and their antioxidant activities. What does a serving constitute? Free Radic. Res. 30: 153-162.

Phillips, D.A. and Kapulnik, Y.(1995). Plant isoflavonoids, pathogens and symbionts. Trends Microbiol. 3: 58-64.

Porter, J.W. and Spurgeon, S.L. ed. (1981). Biosynthesis of Isoprenoid Compounds, v. 1 and 2. John Wiley and Sons, New York, NY.

Savoure, A., Magyar, Z., Pierre, M., Brown, S., Schultze, M., Dudits, D., Kondorosi, A. and Kondorosi, E.V. (1994). Activation of the cell cycle machinery and the isoflavonoid biosynthesis pathway by active Rhizobium meliloti Nod signal molecules in Medicago microcallus suspensions. EMBO J 13: 1093-102.

Tan, X.P., Liang, W.Q., Liu, C.J., Luo, P., Heinstein, P. and Chen, X.Y. (2000). Expression pattern of (+)-delta-cadinene synthase genes and biosynthesis of sesquiterpene alde- hydes in plants of Gossypium arboreum L. Planta 210: 644-651.

Threlfall, D.R. and Whitehead, I.M. (1988). Co-ordinated inhibition of squalene synthase and induction of enzymes of sesquiterpenoid phytoalexin biosynthesis in cultures of $\mathrm{Ni}$ cotiana tabacum. Phytochemistry 27: 2567-2580.

Uhlmann, A. and Ebel, J. (1993). Molecular cloning and expression of 4-coumarate:coenzyme A ligase, an enzyme involved in the resistance response of soybean (Glycine max L.) against pathogen attack. Plant Physiol. 102: 1147-56.

Van Etten, H.D., Mathews, D.E. and Mathews, P.S. (1989). Phytoalexin detoxification: importance for pathogenicity and practical implications. Annu. Rev. Phytopath. 27: 143-164.

Voegeli, U. and Chappell, J. (1988). Induction of sesquiterpene cyclase activities in plant cell cultures treated with fungal elicitor. Plant Physiol. 88: 1291-1296.

Welle, R. and Grisebach, H. (1989). Phytoalexin synthesis in soybean cells: elicitor induction of reductase involved in biosynthesis of 6'-deoxychalcone. Arch Biochem Biophys. 272: 97-102.

Yoshioka, H., Yamada, N. and Doke, N. (1999). cDNA cloning of sesquiterpene cyclase and squalene synthase, and expression of the genes in potato tuber infected with Phytophthora infestans. Plant Cell Physiol. 40: 993-998. 